\title{
Interest Rate Liberalization and Credit to Private Sector in Nigeria: ARDL-Cointegration Approach
}

\author{
Peter Ego Ayunku \\ Associate Professor of Finance and Banking, \\ Department of Banking, Finance \& Insurance Niger Delta University, \\ Wilberforce Island, Bayelsa State, Nigeria. \\ E-mail: peterayunku@yahoo.com
}

Received: May 5, 2019 Accepted: May 30, 2019 Published: June 3, 2019

doi:10.5296/ifb.v6i1.14883 URL: http://dx.doi.org/10.5296/ifb.v6i1.14883

\begin{abstract}
This study examined the relationship between interest rate liberalization and credit to private sector in Nigeria, using annual time series data spanning from 1986 to 2016. The study employed ARDL (p,q) model as suggested by Pesaran and Shin (1997) to analyzed the data. The study commenced with the Augmented Dickey Fuller (ADF) unit root test and the results reveal that all the variables were integrated at order I (1). While the result of the estimated coefficient reveals that interest rate with the first lag was positive and statistically insignificant. And that a percent increase will lead to a 0.087 percent increase in the dependent variable (interest rate). In the same vain Inflation rate has a negative influence on interest rate and was not statistically significant. A percentage change in inflation will lead to 0.08 percent decrease in interest rate. The coefficient of determination $\left(\mathrm{R}^{2}=0.78\right)$ of the estimated model ARDL $(1,2,4,1)$ shows that about 78 percent of the systematic variation in interest rate(INT) is totally explained and well accounted for by the independent variables. This implies that the ARDL $(1,2,4,1)$ model is of goodness of fit and is quite adequate. Base on the findings the study recommends amongst others that monetary authority should pursue interest rate liberalization policies so as to enhance credit to private sector growth that would further engender economic growth and development in Nigeria.
\end{abstract}

Keywords: ARDL-Cointegration, ARDL Bounds Test, Integration, Sectoral Allocation, Inefficiencies, Quantitative, Liberalisation, Adequate. 


\section{Introduction}

In Nigeria, prior to the introduction of the structural adjustment programme (SAP) in 1986, the Nigerian economy most especially the financial sector was highly characterized by rigid exchange and interest rate controls, with mandatory sectoral allocation of bank credit and quantitative ceiling in bank credit to the private sector, which engendered distortion and inefficiencies that resulted to low direct investment. Thus financial liberalization measures were adopted, which include interest rate, exchange rate and others (Okapra, 2010).

Interest rate liberalization therefore, as a process in which monetary authorities removed control of interest rate ceiling or cap by allowing the forces of demand and supply to determine interest rate in an economy. Dabo (2012) opined that the removal of the elements of financial repression, particularly controlled interest rates, financial sector reforms are expected to lead to higher nominal and real interest rates.

It has been asserted that liberalization encourage the adaption of policies that promote the greatest possible use of market forces and competition and would also promote external participation in the economy and that foreign private investment is attracted to some areas of public enterprises (Pearce, 1998).

Interest rate facilitates the flow of funds from lenders to borrowers. It is the cost of borrowing, and shows what a borrower pays to the lender for the use of money and that high interest rate discourages borrowing and encourages which ultimately slow down the economy, while on the other hand low interest rate encourage borrowing and economic growth and that the lower the interest rate the higher the profit expectation. Conversely, the higher the interest rate, the lower the profit margins (CBN, 2016).

Interest rate can also be described as the proportion of an amount loaned which a lender charges as interest to the borrower, it is the rate a bank or a lender charges for money borrowed.

Furthermore, Mckinnon (1973) and Shaw (1973) analyzed the benefits of if not eliminating financial repression, at least reducing its impact on the domestic financial system within developing countries hypotheses and concluded that alleviating financial restrictions in developing countries by allowing market forces to determine real interest rates can exert a positive effect on growth rates as interest rates rise towards their competitive market equilibrium. According to them, artificial ceilings on interest rates reduce savings capital accumulation, and discourage the efficient allocation of resources.

Mckinnon (1973) pointed out that financial repression can lead to dualism and that firms having access to subsidized funding would tend to choose relatively capital intensive technologies.

The results and research conducted by previous researchers has been mixed and inconclusive. Adofu, Abula and Audu( 2010) examine the effect of interest rate deregulation on agricultural sector productivity in Nigeria for the period 1986-2005 using ordinary least square technique to analyze the variables and the finding suggested that interest rate has positive significant 
effecton agricultural output. Also Obamuyi (2009) investigated the relationship between interest rate and economic growth in Nigeria, using annual data for the period 1970-2006 and found that lending rate exerts a significant negative impact on growth.

In view of the above, this study is therefore aimed at filling the research gap by empirically investigating interest rate liberalisation and credit to private sector in Nigeria, using advance econometric model ARDL-Cointegration techniques to analyzed the data

In the light of the above, the rest of the paper is structured as follows; section two review of relevant literature, section three discusses the methodology, while section four highlights the results and discussions, section five concludes the paper and policy recommendation are offered.

\section{Review of Relevant Related Literature}

There has been a debate in the body of literature the relationship between interest rate liberalisation and economic growth. This study however looked at the relationship between interest rate liberalisation and credit toprivate sector in Nigeria.

Dabo (2012) examined whether the financial performance of the banks improved after the liberalization policy. Using Wilcoxon signed rank test to test for changes in the following performance measure variables, such as profitability, deposit, lending and operating efficiency. The results of the study lend support to the proposition that banks in Nigeria witnessed performance improvement following the liberalization policy.

Okpara (2010) studied the effect of financial liberalization on selected macroeconomic variable such as Gross Domestic Product (GDP), Foreign Direct Investment, financial deepening, savings and inflation rate in Nigeria using parametric paired sample statistics for t-test and non parametric Wilcoxon signed rank test to determined whether significant difference exists between pre/post liberalization macroeconomic variables. The result shows that while real GDP recorded highest positive and significant contribution, national savings and foreign direct investment made negative and significant contribution to financial deepening and inflation rate did not discriminate significantly between non financial and financial liberalization.

Adofu, Abula and Andu (2010) examined the effect of interest rate deregulation on agricultural sector productivity on Nigeria for the period 1986-2005) Using Ordinary Least Square (OLS) techniques to analyzed the variables and their findings suggested that interest rate has a positive significant effect on agricultural output.

OkoyeNwakoby and Modebe (2015) investigated the effect of the interest rate liberalization policy on the performance of the industrial sector in Nigeria, using Vector Error Correction Model (VECM). The results suggest that exchange rate volatility has an insignificant positive impact on industrial output performance. It also shows an evidence of significant positive impact of lending rate and financial depth on industrial output growth. The study further shows that inflation has a significant negative effect on the output of the sector.

Also Obamuyi (2009) investigated the relationship between interest rate and economic 
growth in Nigeria, using annual data for the period of 1970-2006 and find that lendingand inflation rate exerts a significant negative impact on economic growth while deposit rate shows a significant positive effect on economic growth.

Similarly, Orji, Orji and Mba (2015) examined the impact of financial liberalization on output growth in Nigeria over the period of 1986-2011 using Ordinary Least Square (OLS) method of estimation in its analysis and the empirical findings suggested that financial liberalization policy proxies by credit to private sector/GDP is negatively related to output growth in Nigeria within the period under review. The study suggested that credit to private sector may have been used for buying and selling of consumables or diverted to some unproductive ventures. The result also shows that there is unidirectional causality running from output growth (LRGDP) to financial liberalization.

Nadeem, KhalilIrfan and Muhammed (2016) explored the long and short term effect of interest rate on private sector credit on Pakistan for the period of 1975-2011. The stationary of data, was analyzed using Augmented Dickey Fuller and Philip Perron Test. They also applied Autoregressive Distributed Lag (ARDL) model for analyzing the long and short term relationship and the results revealed significant negative sector credit in the long and short run. The result also indicated significant positive effect of inflation on private sector credit in the long and short run. However, exchange rate was found to have no effect on private sector credit.

In a similar vein, Owusu and Odhiambo (2013) investigated the long run relationship between economic growth and financial liberalization using the Authoregressive Distributed Lag (ARDL) bounds testing approach for the period 1969-2008 and found that financial liberalization policies have a positive and significant effect on economic growth in Nigeria both in the short and long run. The study therefore recommends that appropriate financial liberalization policies should be pursued in Nigeria, in order to foster economic growth.

Odhiambo (2009) examined the dynamic impact of interest rate reforms and economic growth in Zambia using two models in a pair wise fashion, the study finds strong support for the positive impact of interest rate liberalization on financial deepening. In addition, the study also finds that financial deepening, which results from interest rate liberalization, granger causes economic growth and that logged financial depth leads to further financial deepening while saving and economic growth granger cause each other and financial development granger causes savings in the long run.

Shen and Bian (2007) estimated the implicit interest rates in China, using headquarters-level data of 88 commercial banks from bank scope and branch level data of 317 branches in 90 countries and 14 provinces for the period 2005-2013, using some econometric methods for both heterogeneity and spatial correlation in banks behavior to better capture the characteristics of Chinese banking industry and the findings revealed that first, the estimated mean explicit interest rate is between 70 percent and 78 percent of explicit interest rate ignoring implicit interest rates results in underestimation of finding costs. 
Secondly, a one percent increase in deposit interest rates is estimated to decrease implicit interest rates by 0.44 percent, implying that the cost of interest rate liberalization will be smaller than the increase in deposit interest rates. Thirdly, small share-holding banks, city commercial banks and rural commercial banks pays higher implicit interest rates than large state-owned banks. They conclude by stating that to promote efficient resource allocation, therefore, interest rate liberalization needs to be firmly pursued, but its impact on different types of banks needs to be closely monitored to minimize disruptions to the real economy.

Ifionu (2015) studied the influence of interest rate volatility on the performance of the Nigerian economy over the time from 1986-2015 utilizing secondary data racked from the statistical report of the apex Nigerian bank and using techniques such as unit root test Generalized Autoregressive Conditional Heteroscedasticity (GARCH), impulse Response Output and Variance Decomposition Test to evaluate the variables such as interest rate, inflation rate, exchange rate against a sole indicator of economic performance (i.e.) Gross Domestic Product (GDP) and it was discovered that despite the short run influx of the spill over vitality of interest rate and inflation rate, there exists no long run volatility, influence of interest rate on economic performance in Nigeria.

In view of the above, this study is carried out so as to bridge the research gab as most studies on the above are based on investigating the relationship between interest rate liberalization and economic growth andthat the results are varying and inclusive as observed.

\section{Methodology}

\subsection{Research Design}

The study adopted Ex-post facto research design and the variables of the study are interest rate, exchange rate, inflation rate and credit to private sector. We used secondary sources of data and were sourced from Central Bank of Nigeria (CBN) statistical bulletin and annual statement of accounts, National Bureau of Statistics (NBS) and Nigeria Deposit Insurance Corporation (NDIC), respectively

In order to examine the relationship between the variables of interest, the study adopted the ARDL (p,q) model as suggested by Pesaran and Shin (1993) for the estimation of cointegration time series data and Error Correction Model (ECM). Thus, the ARDL (p.q) model is specified as follows;

$$
\begin{gathered}
y_{t}=\propto_{0}+\propto_{1} t+\sum_{1=1}^{p} \emptyset i y t-i+\beta_{x t-i}+\sum_{1=0}^{a-I} \beta^{\prime i} \Delta_{x t-i}+\mu_{t} \ldots \ldots \ldots \ldots \ldots(1) \\
\Delta_{x t}=P_{1} \Delta_{x t-i}+P_{2} \Delta_{x t-2}+\ldots \ldots+P_{S} \Delta_{X T-S}+\cdots{ }^{\varepsilon} \ldots \ldots \ldots \ldots \ldots \ldots(2)
\end{gathered}
$$

Where;

$\mathrm{X}_{\mathrm{t}}=$ is the $\mathrm{K}-$ dimentional $\mathrm{i}(\mathrm{i})$ variables that are not cointegrated among themselves.

$\mu_{\mathrm{t}} \& \epsilon_{\mathrm{t}}=$ are the serially uncorrelated with zero means and a constant variance - coraviances 
$\mathrm{P}_{1}=\mathrm{KxK}$ coefficient matrices such tha. $\mathrm{t}$ the vector autoregressive processes in $\Delta_{\mathrm{xt}}$ is stable

\subsubsection{Operational Definition of Variables}

Interest rate: Is the amount charge and is expressed as a percentage of principal by a lender to a borrower for the use of an asset. Interest rate can be described as the price paid for money borrowed.

Inflation rate: Inflation rate can simply be defined as a persistent increase in general price level for goods and services in an economy over a period of time inflation rate is measured as an annual percentage increase or expressed as a percentage, which further indicates a decrease in the purchasing power of nation's currency.

Exchange rate: Is the rate at which one currency will be exchange for another. It is the price of a unit of foreign currency.

Credit to private sector: This essentially refers to financial resources provided to private sector by banks or financial institution through loans and advances.

\section{Results and Discussions}

\subsection{Unit Root Test}

An ARDL model does not required pre-test for variables for unit root. However, we commenced our analysis by ensuring that the variables of interest are integrated at order 1(0) or 1(1) so as to meet one of the basic assumptions of ARDL estimation.

Table 1, below reported the ADF Unit root test results and the results confirmed that all variables were integrated at order 1(1) and therefore, we do not reject the null hypothesis and thus conclude that there is no unit root in order 1(2).

Table 1. Augmenteddicker fuller (ADF) unit root test results

\begin{tabular}{llll}
\hline Variables & ADF_Statistics & Critical values at 5\% & Order of Integration \\
\hline Int. & -5.437432 & -1.953381 & $1(1)$ \\
Inf & -4.836276 & -1.954414 & $1(1)$ \\
Ex & -5.142724 & -1.952910 & $1(1)$ \\
PSC & -5.684161 & -1.957204 & $1(1)$ \\
\hline
\end{tabular}

Source: Authors Computation.

The above result further indicates that the ADF-test statistics values are higher than their respective critical values at $1 \%, 5 \%$ and $10 \%$ respectively.

\subsection{ARDL Bounds Test Results}

From table 2 below, the computed F-statistics value is 7.398093 while the critical value bounds for this test as suggested by Pesaran, Shin and Smith (2001) at the 95\% level is given as $3.23-4.36$, the lower and upper bands. Since the F-statistics value exceeds or is greater 


\section{Macrothink}

than the lower and upper bounds as given above, the null hypothesis of no long run relationship between the variables is therefore rejected and concludes that there exists a long run relationship between the variables such as INT, INF, EXR and PSC.

Based on the above results, we now proceeds to perform an ARDL to cointegration model estimation.

Table 2. ARDL Bounds Test Results

\begin{tabular}{|c|c|c|}
\hline \multicolumn{3}{|c|}{$\begin{array}{l}\text { Date: 01/06/19Time: 19:40 } \\
\text { Sample: } 19902016 \\
\text { Included observations: } 27\end{array}$} \\
\hline \multicolumn{3}{|c|}{ Null Hypothesis: No long-run relationships exist } \\
\hline Test Statistic & Value & $\mathrm{K}$ \\
\hline F-statistic & 7.398093 & 3 \\
\hline \multicolumn{3}{|c|}{ Critical Value Bounds } \\
\hline Significance & I0 Bound & I1 Bound \\
\hline $10 \%$ & 2.72 & 3.77 \\
\hline $5 \%$ & 3.23 & 4.35 \\
\hline $2.5 \%$ & 3.69 & 4.89 \\
\hline $1 \%$ & 4.29 & 5.61 \\
\hline
\end{tabular}

Source: Authors Computation

\subsection{ARDL Estimation Results}

The estimated coefficient of interest rate with the first lag as positive and statistically insignificant. A percent increase in interest rate will lead to 0.087 percent increase in the dependent variable (interest rate). Inflation rate has a negative influence on interest rate and is not statistically significant. A percent change in inflation will lead to 0.008 percent decrease in interest rate.

Furthermore, inflation rate with the first lag has positive and statistically insignificant influence on interest rate that one percent increase will lead to 0.006 percent increase in interest rate, while inflation rate with second lag has a negative and statistically insignificant influence on interest rate, exchange rate has a positive and statistical insignificant influence on interest rate and that 1.03 percent increase will lead to an 1.03 increase in interest rate.

Exchange rate with first, second and fourth lag has a negative effect on interest rate. However, exchange rate with the fourth lag is statistically significant while others were statistically insignificant.

This result implies that one percent increase will lead to $1.96,0.28,4.74$ percent decrease in interest rate respectively. Furthermore, exchange with the third lag has a positive and statistically significant effect on interest rate. Thus one percent increase will lead to 6.2 percent increase in interest rate. . Similarly, the estimated coefficient of credit to private 
sector has a negative and statistically insignificant effect on interest rate and that one percent increase will lead to 5.8 decrease in interest rate while on the other hand credit to private sector with the first lag has a positive and statistically insignificant influence on interest rate, one percent increase will lead to 4.36 percent increase in interest rate.

The coefficient of determination $\mathrm{R}^{2}$ is 0.78 of the estimated model of ARDL $(1,2,4,1)$ which shows that about $78 \%$ of the systematic variation in interest rate is jointly explained and iswell accountedfor by the independent variables. The F-statistics which is used to test for the overall significance of a regression model indicates that the overall model is statistically significant with its F-statistic value of 4.82 and P-value of 0.00 . This result further implies that the ARDL model is of goodness of fit. The Durbin-Watson (DW) statistics result of 2.29 indicates that there is no evidence of first order serial or autocorrelation issue or problem in the model

Table 3. ARDL Estimation Results

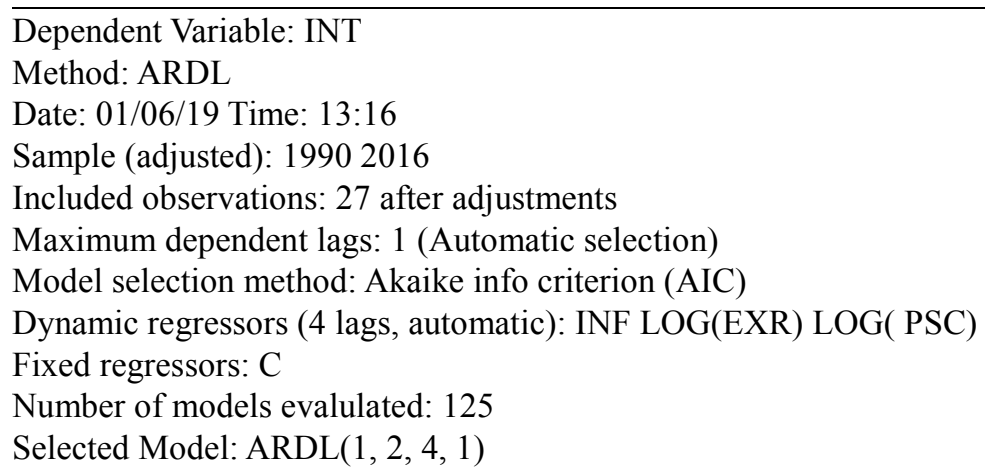

\begin{tabular}{|c|c|c|c|c|}
\hline Variable & Coefficient & Std. Error & t-Statistic & Prob.* \\
\hline INT(-1) & 0.087159 & 0.178315 & 0.488790 & 0.6321 \\
\hline INF & -0.008412 & 0.043124 & -0.195066 & 0.8480 \\
\hline $\operatorname{INF}(-1)$ & 0.056229 & 0.052336 & 1.074387 & 0.2996 \\
\hline $\operatorname{INF}(-2)$ & -0.103880 & 0.052457 & -1.980267 & 0.0663 \\
\hline LOG(EXR) & 1.035393 & 2.156110 & 0.480213 & 0.6380 \\
\hline LOG(EXR(-1)) & -1.958895 & 2.303097 & -0.850548 & 0.4084 \\
\hline $\operatorname{LOG}(\operatorname{EXR}(-2))$ & -0.282643 & 2.230719 & -0.126705 & 0.9009 \\
\hline $\operatorname{LOG}(\operatorname{EXR}(-3))$ & 6.194162 & 2.192271 & 2.825455 & 0.0128 \\
\hline $\operatorname{LOG}(\operatorname{EXR}(-4))$ & -4.742922 & 1.774342 & -2.673059 & 0.0174 \\
\hline LOG(PSC) & -5.825907 & 3.310322 & -1.759921 & 0.0988 \\
\hline $\operatorname{LOG}(\operatorname{PSC}(-1))$ & 4.360790 & 3.123466 & 1.396138 & 0.1830 \\
\hline $\mathrm{C}$ & 28.23107 & 6.075752 & 4.646514 & 0.0003 \\
\hline R-squared & 0.779555 & \multicolumn{2}{|c|}{ Mean dependent var } & 18.62741 \\
\hline Adjusted R-squared & 0.617895 & \multicolumn{2}{|c|}{ S.D. dependent var } & 3.727131 \\
\hline S.E. of regression & 2.303914 & \multicolumn{2}{|c|}{ Akaike info criterion } & 4.808198 \\
\hline Sum squared resid & 79.62029 & \multicolumn{2}{|c|}{ Schwarz criterion } & 5.384126 \\
\hline Log likelihood & -52.91067 & \multicolumn{2}{|c|}{ Hannan-Quinn criter. } & 4.979451 \\
\hline F-statistic & 4.822186 & \multirow{2}{*}{\multicolumn{2}{|c|}{ Durbin-Watson stat }} & 2.290696 \\
\hline Prob(F-statistic) & 0.002946 & & & \\
\hline
\end{tabular}

*Note: p-values and any subsequent tests do not account for model selection. 


\subsection{ARDL Cointegrationand Long Run Results}

From table 4 below, the ARDL cointegration and Long run results indicate that there exists a stable long run relationship among the variables. The coefficient of the ECM value as represented by cointeq(-1) as expected has the correct negative sign of 0.96 and was statistically significant when viewed. This further implies that the speed of adjustment from the long run to equilibrium is corrected by about 96percent, which is quite high. The highly significant value of the Error Correction Model (ECM) further confirms and validates that there exist a stable long run relationship among the variables.

Table 4.ARDL Cointegrating and Long Run Result.

\begin{tabular}{|c|c|c|c|c|}
\hline \multicolumn{5}{|c|}{$\begin{array}{l}\text { ARDL Cointegrating And Long Run Form } \\
\text { Dependent Variable: INT } \\
\text { Selected Model: ARDL }(1,2,4,1) \\
\text { Date: 01/06/19 Time: } 19: 42 \\
\text { Sample: } 19862016 \\
\text { Included observations: } 27\end{array}$} \\
\hline \multicolumn{5}{|c|}{ Cointegrating Form } \\
\hline Variable & Coefficient & Std. Error & t-Statistic & Prob. \\
\hline$\overline{\mathrm{D}(\mathrm{INF})}$ & 3.869817 & 0.043124 & 89.737401 & 0.0000 \\
\hline $\mathrm{D}(\mathrm{INF})$ & 2.676354 & 0.052457 & 51.019508 & 0.0000 \\
\hline DLOG(EXR) & 20.465931 & 2.156110 & 9.492062 & 0.0000 \\
\hline DLOG(EXR(-1)) & 0.282643 & 2.230719 & 0.126705 & 0.9009 \\
\hline DLOG(EXR(-2)) & -6.194162 & 2.192271 & -2.825455 & 0.0128 \\
\hline DLOG(EXR(-3)) & 4.742922 & 1.774342 & 2.673059 & 0.0174 \\
\hline DLOG(PSC) & -5.825907 & 3.310322 & -1.759921 & 0.0988 \\
\hline CointEq(-1) & -0.964712 & 0.178315 & -5.410161 & 0.0001 \\
\hline \multicolumn{5}{|c|}{ Cointeq $=$ INT $-(1.2371 *$ INF $+20.3953 *$ LOG(EXR)-1.5187*LOG(PSC) +29.2637) } \\
\hline \multicolumn{5}{|c|}{ Long Run Coefficients } \\
\hline Variable & Coefficient & Std. Error & $\mathrm{t}$-Statistic & Prob. \\
\hline $\mathrm{INF}$ & 1.237119 & 0.222769 & 5.553382 & 0.0001 \\
\hline LOG(EXR) & 20.395338 & 3.713319 & 5.492482 & 0.0001 \\
\hline LOG(PSC) & -1.518709 & 0.783879 & -1.937428 & 0.0718 \\
\hline $\mathrm{C}$ & 29.263715 & 5.519734 & 5.301653 & 0.0001 \\
\hline
\end{tabular}

Source: Authors Computation

Table 5.Breuch - Godfrey Serial Correlation LM: Test

\begin{tabular}{lll}
\hline F-Statistic & 1.360478 Prob.F(2,13) & 0.2907 \\
Obs*R-Squared & 4.673113 Prob. Chi-squared(2) & 0.0967 \\
\hline Source: Authors Computation & &
\end{tabular}

From table 5 above, the LM test result indicates that the residuals are homoskedasticity (no serial correlation) since the P-value of 0.2907 as shown above is greater than $5 \%$ level of significance. 
Thisfindings are partially consistent with that of Nadeen, Khalil and Irfan (2016) andOwusu and Odhiambo (2013).

\section{Conclusion and Recommendations}

This study examined the relationship between interest rate liberalization and credit to private sector in Nigeria using an annual time series data spanning from 1986-2016. The study used ARDL (p.q) model as suggested by Pesaran and Shin (1997) to analyze the data. The results reveals that the coefficient of determination $\left(R^{2}\right.$ is 0.78$)$ of the estimated ARDL model $(1,2,4,1)$ shows that about 78 percent of the systematic variation in interest rate is jointly explained and is well accounted for by the independent variables. The F-statistics which is used to test the overall significance of the regression model indicates that the model is adequate and is statistically significance with its F-statistic values of 4.82 and P-values of 0.00 which also further confirm that the ARDL model is of goodness of fit.

Furthermore, the Durbin-Watson (DW) statistics result of 2.29 indicates that there is no evidence of first order serial or autocorrelation issue of problem in the model.

Base on the above findings, the study recommends amongst others that interest rates liberalization policy in Nigeria has some mixed feelings and that monetary authorities should pursue interest rate liberalization policies effectively with a view to further enhances credit to private sector which would ultimately engendered economic growth and development in Nigeria.

\section{References}

Adofu,J., Abula,M., \&Audu, S. I. (2010).An Assessment of the Effects of Interest rate Deregulation in Enhancing Agricultural Productivity in Nigeria. Current Journal Economic Theory,2(2), 82-86.

CBN.(2016). Interest Rate, Education in Economic Series 3.

Dabo, Z. (2012). The Impact of Financial Liberalization on the Performance of Banks in Nigeria.Procedia-Social and Behavioral Sciences,62, 548-554.https://doi.org/10.1016/j.sbspro.2012.09.091

Ifionu, B.P. (2015). Interest Rate Volatility and Performance of the Nigerian Economy. Nigerian Journal of Financial Research,10(2), 11-22.

Jhingan, M.L. (2010).Macroeconomic Theory. $12^{\text {th }}$ Revised and Enlarged Edition Vrinda Publications (P) Ltd Dehi, India.

McKinnon, R. I. (1973).Money and Capital in Economic Development. Washington: The Brookings Institution.

Nadeem, A., Khalil, J., Irfan, U.,\&Muhammed, A. (2016). Impact of Interest Rate on Private Sector Credit, Evidence from Nigeria. Jorinah Business Review,4(1), 47-52.

Oawumam, P. A. (1993). Recent Developments in Nigerian Financial Services Industry; Problems and Challenges. An Address at Dinner of CIBN, Lagos. 
Obarnuyi, T. M. (2009). An investigation of the Relationship Between Interest rate and Economic Growth in Nigeria.Journal of Economics and International Finance, 1(4), 93-98.

Odhiambo, N. M. (2009). Interest Rate Liberalization and Economic Growth in Zambia: A Dynamic Linkage. African Development Review, 21(3), 541-557. https://doi.org/10.1111/j.1467-8268.2009.00222.x

Ojo, M. O. (1993).A Review and Appraisal of Nigerians Experience with Financial Sector Reform.Occasional Paper 8 (CBN) Lagos.

Okoye, L. U., Nwakoby, C. J.,\&Modebe, N. J. (2015). Interest Rate Reform and Real Sector Performance Evidence from Nigeria. African Banking and Finance Review,2(1), 97-114.

Okpara, G. C. (2010). The Effect of Financial Liberalization on Selected Macroeconomic Variables: Lesson from Nigeria. The International Journal of Applied Economics and Finance, (4), 53-61. https://doi.org/10.3923/ijaef.2010.53.61

Orji, A, Orji, O. I. A.,\&Mba, P. N. (2015).Financial Liberalization and Output Growth in Nigeria: Empirical Evidence from Credit Channel. International Journal of Economics and Financial Issues, 5(1), 297-311.

Owusu, E. L.,\&Odhiambo, M. (2013). Financial Liberalization and Economic Growth in Nigeria: An ARDL Bounds Approach. Journal of Economic Policy Reform,17(2), 164-177.https://doi.org/10.1080/17487870.2013.787803

Pearce, D. W. (1998).Macmillan Dictionary of Modern Economics. Macmillan Press Ltd.

Pesaran, M. H.,\& Shin, Y. (1997).An Autoregressive Distributed Lag Modeling Approach to Cointearation Analysis. Paper Presented at the Symposium at the Contennial of Raguar Frisch, the Norwegian Academy of Science and Letters, Oslo.

Pesaran, M. H., Shin, Y., \& Smith, R.J. (2001).Bounds Testing Approarches to the Analysis of Level Relationship.Journalof Applied Econometrics, 16(3), 289-326.https://doi.org/10.1002/jae.616

Shaw, E. (1973).Financial Deepening in Economic Development. New York: Oxford University Press.

Shen, Y., \&Bian, W. (2017). Interest Liberalization and the Estimation of Implicit Interest Rates in China's Banking Sector. Asian Economic Papers, 16(3), 287-307.https://doi.org/10.1162/asep_a_00576

\section{Copyrights}

Copyright for this article is retained by the author(s), with first publication rights granted to the journal.

This is an open-access article distributed under the terms and conditions of the Creative Commons Attribution license (http://creativecommons.org/licenses/by/4.0/). 